\title{
SISTEM EKONOMI LAISSEZ FAIRE ADAM SMITH
}

Oleh: Muthia Zhafirah Ali (90100118037)

email:vhiraphila2@gmail.com

Keruntuhan sistem ekonomi sosialis memberi peluang untuk hadirnya sistem ekonomi kapitalis. Namun dalam kenyataannya sistem ekonomi kapitalis juga menuju ke arah kehancuran dan kemunduruan seiring dengan berkembangnya krisis global yang belum menunjukkan tanda-tanda akan membaik sampai saat ini. Sehingga memunculkan berbagai pendapat yang mengatakan bahwa sistem tinggal menunggu saat kehancurannya sebagaimana halnya sistem ekonomi sosialis. (Azhar, 2017) Sistem ekonomi kapitalis merupakan sebuah sistem organisasi ekonomi yang dicirikan oleh hak milik privat atas alat-alat produksi dan distribusi dan pemanfaatannya untuk mencapai keuntungan dalam kondisi yang sangat kompetitif.

Para ahli ekonomi dunia menilai bahwa pemikiran ahli-ahli ekonomi klasik yang dimotori oleh Adam Smith merupakan dasar sistem ekonomi kapitalis. Tokoh-tokoh mazhab klasik mengemukakan bahwa segala kegiatan ekonomi yang diaksanakan secara bebas dinilai akan lebih banyak manfaatnya bagi kalangan masyarakat sebagai keseluruhan dibandingkan kalau segalanya diatur oleh pemerintah dengan kata lain pemerintah ikut campur tangan. Untuk itu peran pemerintah dalam ekonomi kapitalis dibatasi hanya pada prasarana pekerjaan umum serta jasa-jasa publik lainnya. Misalnya mengenai hubungan antara nilai dan harga barang, besarnya upah dan laba, yang satu sama lainnya ditentukan oleh kekuatan-kekuatan pasar dalam persaingan.

Kapitalisme ini merupakan hasil dari pemikiran Adam Smith selaku tokoh mazhab klasik dimana para ahli ekonomi dunia menilai bahwa pemikiran mazhab klasik merupakan dasar sistem ekonomi kapitalis. Sesuai didalam bukunya yang berjudul "The Wealth Of Nation" menerangkan pilar-pilar dari kapitalisme dengan konsep Laissez Faire dan prinsip "The Invisible Hand" yang menjadi pijakan dalam kerangka dasar teori sistem ekonomi kapitalis. (Agustiati, ISSN 1411-3341) 
Sejarah peradaban manusia, ada beberapa bentuk sistem ekonomi yang pernah ditemukan sebagai solusi atas persoalan ekonomi umat manusia salah satunya yaitu sistem ekonomi Laissez Faire yang dikemukakan oleh Adam Smith. Yang dimana Laissez Faire adalah sebuah teori ekonomi yang berkembang dari abad ke-18. Laissez Faire sebuah frasa dari Prancis yang artinya biarkan terjadi. Teori Laissez Faire menganut bahwa pemerintah tidak perlu ikut campur tangan di dalam kegiatan bisnis masyarakat. Kaum kapitalis memandang bahwa kebebasan merupakan suatu kebutuhan bagi individu untuk menciptakan keserasian antara dirinya dan masyarakat. Dan kapitalis juga merupakan suatu kekuatan pendorong bagi produksi karena benar-benar menjadi hak manusia yang menggambarkan kehormatan manusia.

Menurut pandangan Laissez Faire kewajiban negara bukanlah melakukan intervensi untuk menstabilkan distribusi kekayaan atau untuk menjadikan sebuah negara makmur untuk melindungi rakyatnya dari kemiskinan, melainkan bersandar pada sistem pasar dan sumbangan. Para pendukung Laissez Faire juga mendukung ide yang menyatakan bahwa pemerintah tidak boleh menggunakan kekuasaan dan paksaan untuk merusak monopoli de facto. Pendukung dari Laissez Faire juga mendukung ide perdagangan bebasa dalam artian negara tidak boleh melakukan proteksi, seperti tarif dan subsidi di wilayah ekonominya. (Huda, 2016)

Sistem ekonomi kapitalis pasar memainkan peranan yang sangat penting dalam sistem perekonomian. Karena ekonomi kapitalis menghendaki pasar bebas untuk menyelesaikan permasalahan ekonomi, mulai dari produksi, konsumsi dan distribusi. Perilaku kapitalis adalah lasses faire et laisssez le monde va de lui meme yang artinya biarkan ia berbuat dan biarkan ia berjalan, dunia akan mengurus diri sendiri. Maksudnya biarkan perekonomian berjalan dengan sendirinya tanpa intervensi pemerintah, nanti akan ada suatu tangan yang tidak terlihat yang akan membawa perekonomian tersebut ke arah yang seimbang. Jika pemerintah ikut campur tangan maka pasar akan mengalami distorsi yang akan membawa perekonomian pada ketidakseimbangan. Maka dalam paradigma Laissez Faire, mekanisme pasar bebas diyakini akan menghasilkan sesuatu yang adil. (Parakkasi \& Kamiruddin, 2018) 


\section{DAFTAR PUSTAKA}

Azhar. (2017). Antara Ekonomi Islam Dan Ekonomi. Jurnal Islamika, 17, 1-16.

Agustiati. Sistem Ekonomi Kapitalisme. ISSN 1411-3341.

Huda, C. (2016). Ekonomi Islam Dan Kapitalisme (Merunut Benih Kapitalisme dalam Ekonomi Islam). Economica: Jurnal Ekonomi Islam, 7(1), 27-49.

Parakkasi, I., \& Kamiruddin, K. (2018). Analisis Harga Dan Mekanisme Pasar Dalam Perspektif Islam. LAA MAISYIR : Jurnal Ekonomi Islam, 5(1), 107-120. 